\title{
Dinoflagellate cyst biostratigraphy, palynofacies, depositional environment and sequence stratigraphy of the Agardhfjellet Formation (Upper Jurassic-Lower Cretaceous) in central Spitsbergen (Arctic Norway)
}

\author{
Thine Sanne Dalseg ${ }^{1}$, Hans Arne Nakrem² \& Morten Smelror ${ }^{3}$ \\ ${ }^{1}$ BakerHughes, Tanangerveien 501, 4056 Tananger, Norway. \\ ${ }^{2}$ Natural History Museum, University of Oslo, University of Oslo, P.O. Box 1172 Blindern, NO-0318 Oslo, Norway. \\ ${ }^{3}$ Geological Survey of Norway, P.O. Box 6215 Sluppen, NO-7491 Trondheim, Norway.
}

E-mail corresponding author (Thine Sanne Dalseg): thinesd@gmail.com

\begin{abstract}
The Upper Jurassic-Lower Cretaceous in the Isfjorden area (central Spitsbergen), consisting mostly of dark shales, with local carbonate-seep deposits, have been analysed for marine palynomorphs and palynofacies. Two dinoflagellate cyst assemblage zones have been defined in the Slottsmøya Member (Agardhfjellet Formation). The palynostratigraphic zones are established with reference to $\delta^{13} \mathrm{C}_{\text {org }}$ curves, and are correlated with Early Volgian to Late Ryazanian foraminiferal zones and ammonite zones from the same area. A Leiosphaeridia bloom at $45.62 \mathrm{~m}$ in the Janusfiellet profile is correlated with a comparable bloom recovered from several locations on the western Barents shelf. Palynofacies analysis is used to interpret relative sea-level changes and is also used to constrain the sequence stratigraphy of the studied sections at Janusfjellet and Knorringfjellet.
\end{abstract}

Keywords: Mesozoic, stratigraphy, dinoflagellate cysts, palynofacies, Svalbard, Arctic

Received 16. November 2015 / Accepted 30. May 2016 / Published online 4. August 2016

\section{Introduction}

Dinoflagellate cysts have proven to be an important tool for dating and correlation of Mesozoic and Cenozoic strata due to their high abundance in marine sediments, wide geographic distribution, well established taxonomy and a rapid change in morphology (Riding \& Sarjeant, 1985). Due to sensitivity to temperature, salinity and trophic conditions, dinoflagellate cyst taxa are also important tools in palaeoecology and palaeoclimatology studies (Pfiester \& Anderson, 1987; Riding et al., 1999; Palliani \& Riding, 2003).

Several studies of dinoflagellate cyst assemblages in the Upper Jurassic-Lower Cretaceous successions in Svalbard and from the western Barents Sea have been carried out over the last thirty years (Bjærke, 1980; Århus, 1988; Bailey, 1993; Smelror et al., 1998; Smelror \& Dypvik, 2005). This is the first report where informal dinoflagellate cyst zones are established in the Upper Jurassic/Lower Cretaceous in central Spitsbergen.

The aim of the present study has been to establish a palynostratigraphy through the Upper Jurassic to Lower Cretaceous of the upper Agardhfjellet Formation (Oppdalsåta and Slottsmøya members) at Janusfjellet and Knorringfjellet, central Spitsbergen (Fig. 1). The dinoflagellate cyst zones are correlated with ammonite and foraminifera zones established in the same sections, and are further correlated with time-equivalent palynozones defined elsewhere in the Jurassic Boreal Region.

Dalseg, T.S., Nakrem, H.A. \& Smelror, M. 2016: Dinoflagellate biostratigraphy, palynofacies, depositional environment and sequence stratigraphy of the Agardhfjellet Formation (Upper Jurassic-Lower Cretaceous) in central Spitsbergen (Arctic Norway). Norwegian Journal of Geology 96, 119-133. http://dx.doi.org/10.17850/njg96-2-04. 


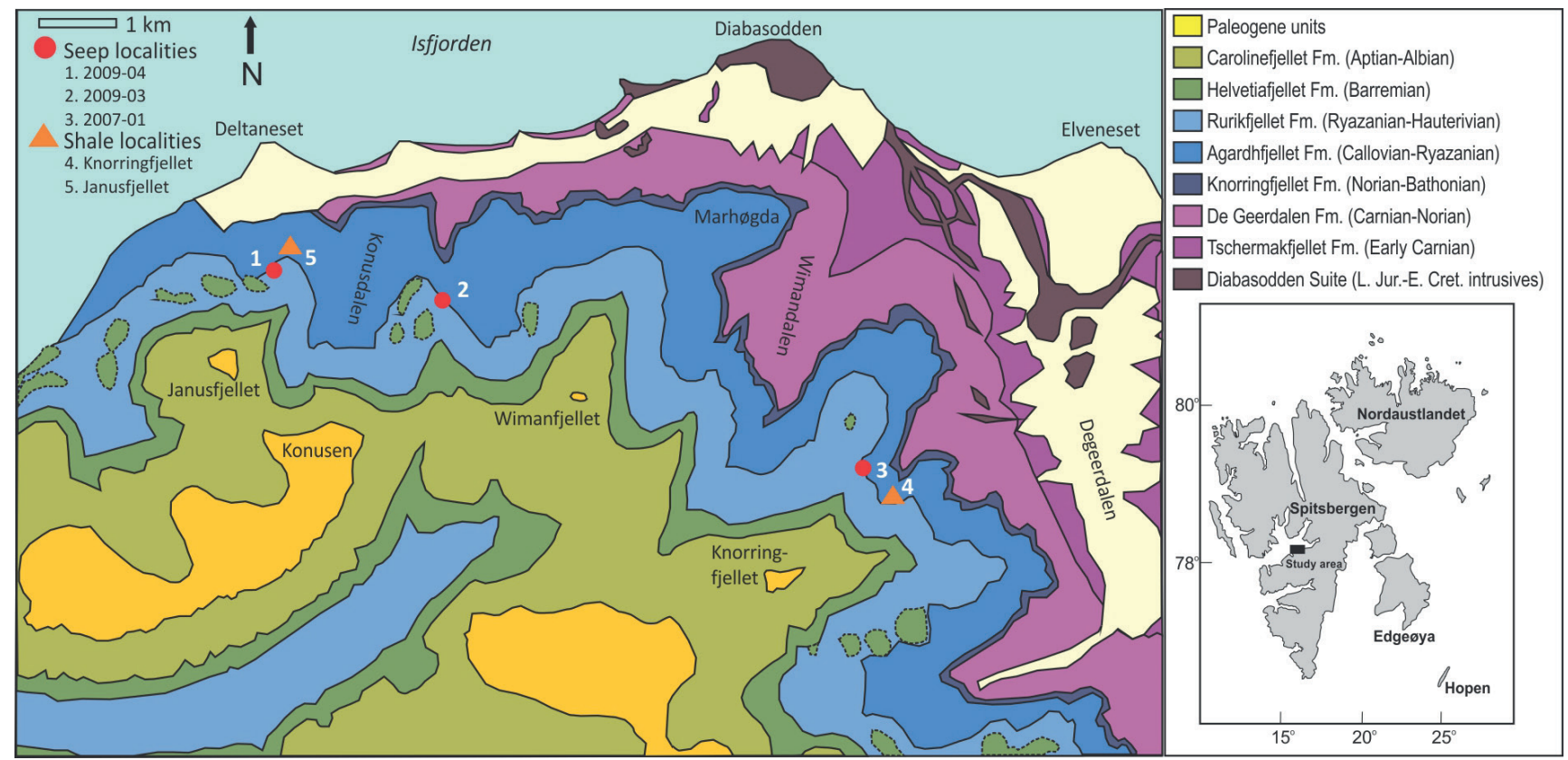

Figure 1. Locations of the studied sections at Janusfjellet and Knorringfjellet in central Spitsbergen, and outcrop map of the Jurassic-Cretaceous formations and Paleogene strata. (Based on an original figure from Dallmann, 1991; modified from Hryniewicz et al., 2012).

The dinoflagellate cyst biozones are correlated with the $\delta^{13} \mathrm{C}_{\text {org }}$ curves from the same sections presented by Hammer et al. (2012) in the studied sections. The semiquantitative distributions of the palynomorphs are used in combination with sedimentological and carbonisotope records to provide a sequence-stratigraphic model for the investigated Upper Jurassic-Lower Cretaceous succession in central Spitsbergen.

\section{Previous studies in the Upper Jurassic- Lower Cretaceous on Svalbard and in the Barents Sea}

Palynomorphs from the Upper Jurassic-Lower Cretaceous of the Agardhfjellet Formation in central Spitsbergen were first described by Bjærke et al. (1976). Subsequently, Bjærke (1980) studied four sections through the Agardhfjellet Formation (former Member) and defined three assemblage zones on the basis of dinoflagellate cysts. In an unpublished report, Århus (1988) presented the first combined dinoflagellate cyst, bivalve-, foraminifera- and ammonite-stratigraphy of the Bathonian-Hauterivian of the Janusfellet Subgroup (former Formation) in central Spitsbergen.

Hammer et al. (2011) reported on hydrocarbon seeps in the Upper Jurassic-Lower Cretaceous Agardhfjellet Formation on Svalbard, and described well preserved faunas in the carbonate-seep bodies. Ammonites from the stratigraphic section covered in the present study have been described by Wierzbowski et al. (2011). Hryniewicz et al. (2012) analysed microfacies from the carbonateseep deposits in the Slottsmøya Member.

Smelror \& Dypvik (2005) studied dinoflagellate cyst assemblages from the Volgian-Ryazanian boundary strata of the western Barents Shelf. They found no dinoflagellate cyst extinctions or first appearances which could be used to determine the Volgian-Ryazanian boundary in the region. The study, however, presents a documented prolific bloom of Leiospaheridia, which is assumed to have been induced by the Mjølnir meteorite impact. According to Smelror et al. (2002) and Dypvik et al. (2004), ejecta from this impact form a marker horizon for the VolgianRyazanian boundary (i.e., the Sindre Bed). Bremer et al. (2004), Dypvik et al. (2006) and Smelror \& Dypvik (2006) also studied sediments in the Barents Sea region affected by the Mjølnir meteorite impact.

\section{Geological setting and lithostratigraphy}

The study covers Upper Jurassic to Lower Cretaceous sedimentary rocks exposed at Janusfellet and Knorringfjellet in Sassenfjorden, central Spitsbergen. The Upper Jurassic-Lower Cretaceous succession was assigned to the Adventdalen Group by Parker (1967), who divided it into four formations; the lowermost Agardhfjellet Formation, the overlying Rurikfellet Formation, the succeeding Helvetiafjellet Formation and the Carolinefjellet Formation on top (Fig. 1). The two lower formations were 


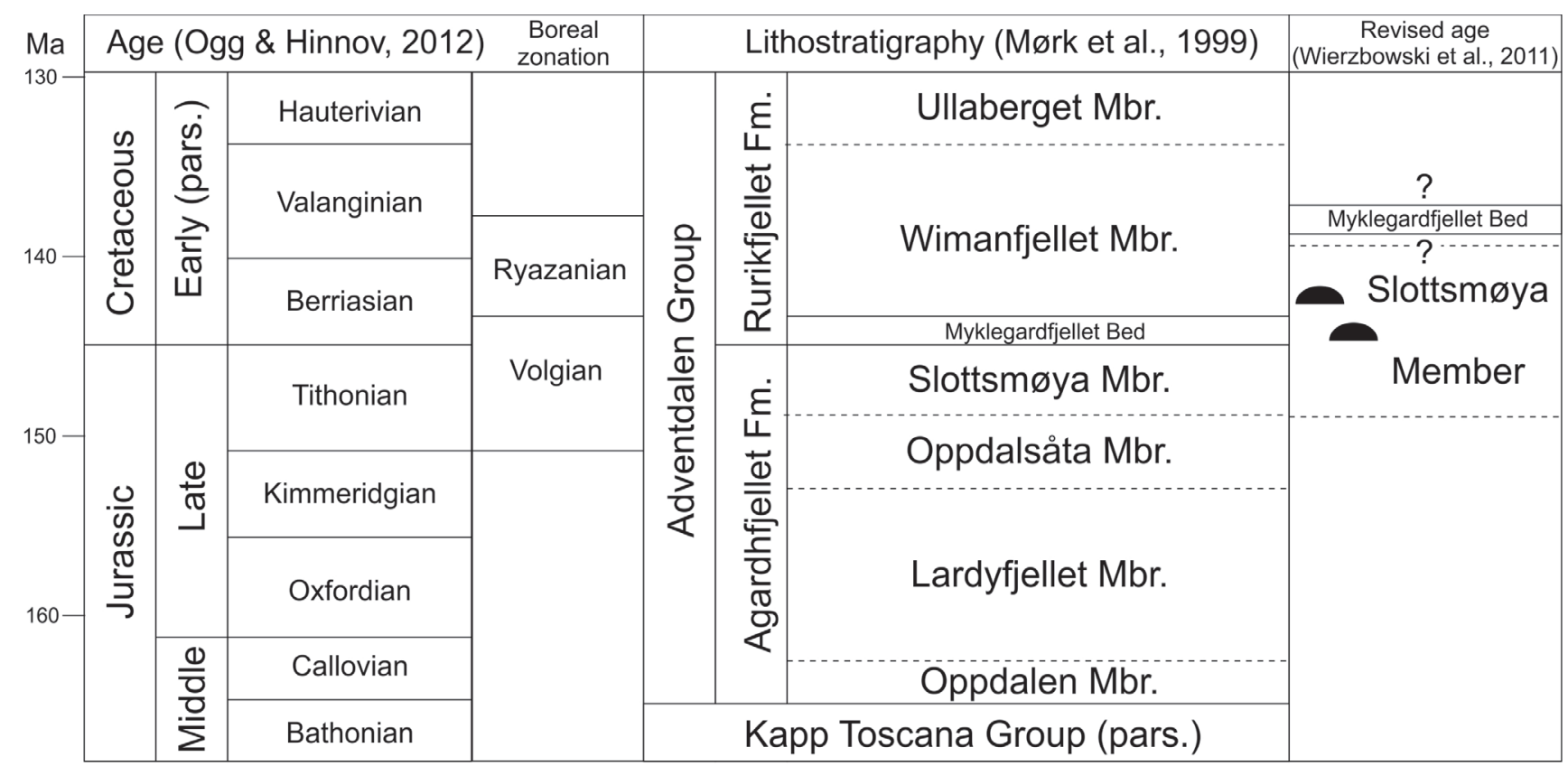

Figure 2. Lithostratigraphic subdivision of the Middle Jurassic-Lower Cretaceous succession on Svalbard. Column to the right shows the revised age of the Slottsmøya Member and Myklegardfjellet Bed as determined by Wierzbowski et al. (2011). Semi-hemispherical symbols mark the occurrences of cold hydrocarbon seep bodies in the section (see also Hammer et al., 2011; Hjálmarsdóttir et al., 2012; Dalseg et al., 2016).

assigned to the Janusfellet Subgroup of Late Jurassic-Early Cretaceous age (Parker, 1967).

The Janusfjellet Subgroup is interpreted as marine shelf to prodeltaic deposits, dominated by shale with subordinate siltstones and sandstones (Dypvik et al., 1991a), indicating a depositional environment varying between relatively shallow to more deep marine. Due to local submarine barriers and basins, resulting from Cimmerian tectonic movements, the bottom water conditions were predominantly dysaerobic to anoxic (Dypvik et al., 1991a). The low sedimentation rate and relatively high organic productivity in the upper water column led to significant accumulations of organic matter in the bottom sediments, which resulted in a total organic carbon content of up to $5 \%$ in some layers (Smelror et al., 2009).

Dypvik et al. (1991a) further divided the Agardhfjellet Formation into four members: the lowermost Oppdalen Member, followed by the Lardyfjellet and Oppdalsåta members, and the Slottsmøya Member uppermost. The palynological samples used in the present study are from the upper part of the Oppdalsata Member and the overlying Slottsmøya Member (Fig. 2).

The upper part of the Oppdalsåta Member consists of silt and fine sand in several coarsening-upward sequences, and the sediments are highly bioturbated. The sandstone beds are assumed to have been deposited as shelf sand ridges (Dypvik et al., 1991a, 1991b). The Slottsmøya Member consists of dark grey to black silty mudstone and paper shale with discontinuous silty, sideritic beds, seep-carbonate bodies and red to yellow siderite and dolomite concretions. The sediments grade into a coarsening-upward shale- silt succession in the upper part (Dypvik et al., 1991a; Hammer et al., 2011). Nagy et al. (2009) interpreted the depositional environment as a deep marine shelf with offshore bars. The increase in thickness of the shales relative to the sandstones towards the east in the Agardhfjellet Formation is interpreted as a result of tectonic movements during the Tertiary (Dypvik et al., 1991a).

The grey shale contains fossil bivalves, brachiopods, gastropods, echinoderms, sponges, ammonites and belemnites, as well as plesiosaur and ichtyosaur remains (Wierzbowski et al., 2011; Hurum et al., 2012; Rousseau $\&$ Nakrem, 2012). The paper shale beds contain relatively few fossils, and bioturbation is not observed (Dypvik et al., 1991a; Hammer et al., 2011).

Several carbonate bodies formed from hydrocarbon seeps are found in the Sassenfjorden area (Hammer et al., 2011; Hjálmarsdóttir et al., 2012; Hryniewicz et al., 2012; Dalseg et al., 2016). The hydrocarbon served as a nutrient for chemoautotrophic microorganisms and constituted a hard substrate, which allowed sessile organisms to settle. In the Sassenfjorden area there is evidently a higher abundance of macrofaunas in some of the seep deposits than in the surrounding mudstones (Hammer et. al., 2011). The carbonate-seep bodies were deposited on an open shelf, in a low-energy regime and oxygen-deficient conditions (Hryniewicz et al., 2012).

Mørk et al. (1999) assigned a Volgian age to the Slottsmøya Member. New biostratigraphic age determinations based 


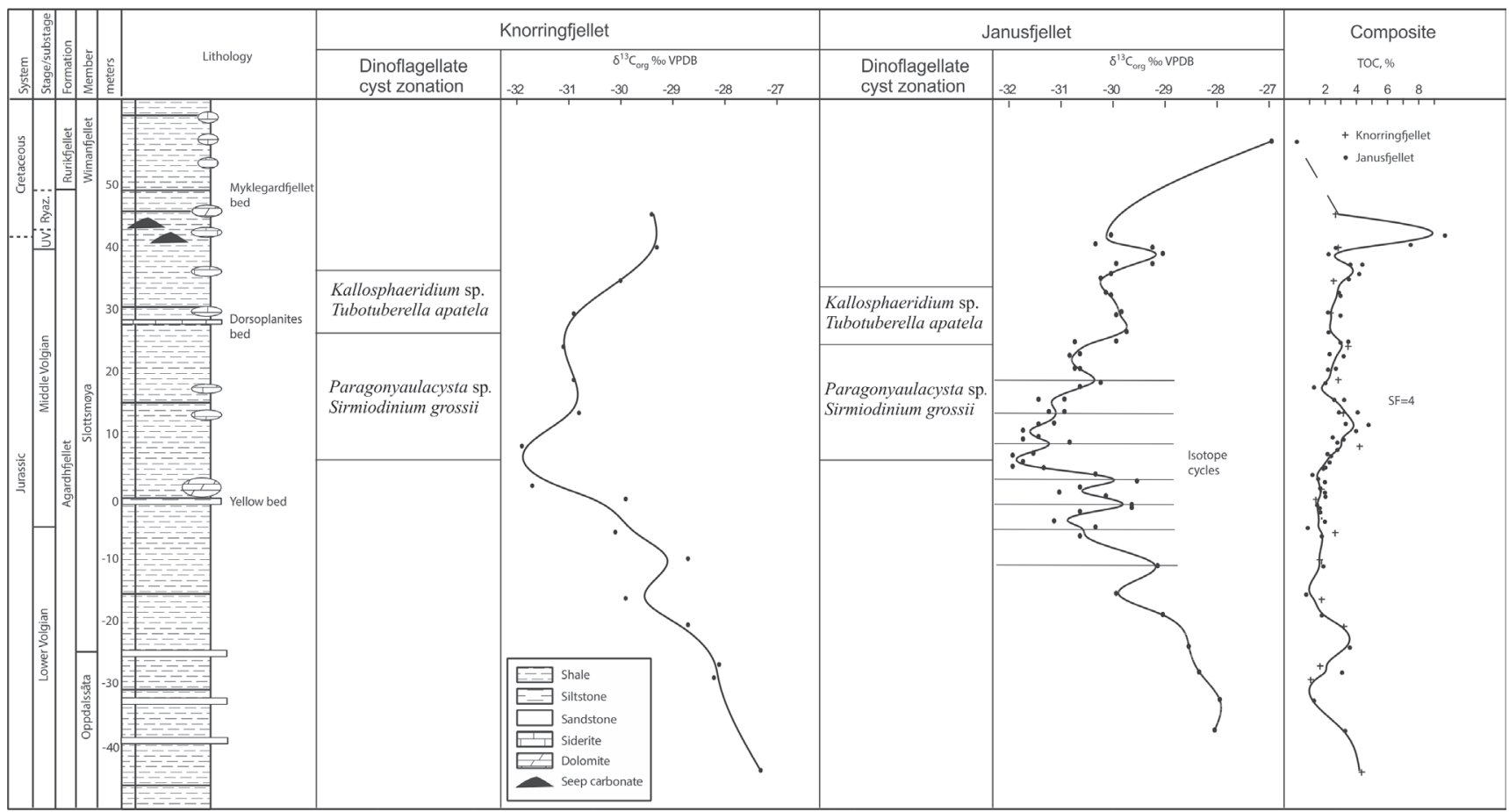

Figure 3. The dinoflagellate cyst zones correlated with the bulk organic carbon isotope curves $\left(\delta^{13} C_{\text {org }}\right.$ curves) and total organic carbon values (TOC). The figure is modified from Hammer et al. (2012), and the TOC and bulk organic carbon isotope data are from the same sample material as used in present study. Abbreviations: VPDB - Vienna Pee Dee Belemnite; TOC - Total Organic Carbon.

on ammonites and agglutinated foraminifera, however, suggest an Early Volgian to Late Ryazanian age (Nagy et al., 2009; Hammer et al., 2011; Wierzbowski et al., 2011; Hjálmarsdóttir et al., 2012).

\section{Material and methods}

The studied material consists of 20 samples from Janusfiellet, 17 samples from Knorringfjellet, and three samples from different carbonate seeps (Fig. 1). Two of the seep samples were collected at Janusfjellet (2009-03 and 2009-04) and one was collected at Knorringfjellet (2007-01; Fig. 1).

The distance between the two localities is only about 10 km (Fig. 1). The samples from Knorringfjellet cover an interval of 84 metres, and the samples from Janusfjellet cover an interval of 46.93 metres. The locations where the seep samples were taken are marked on the map (Fig. 1). The sampled interval covers the upper part of the Oppdalsåta Member to between the sideritic bed (45 $\mathrm{m}$ ) in the upper part of the Slottsmøya Member and the Myklegardfjellet Bed (Fig. 2).

The lithological log of the Slottsmøya Member and the upper part of the Oppdalsåta Member, presented in Collignon (2011), identifies the Dorsoplanites bed at 27 metres above a yellow bed marking the 0 -level in the studied sections
(Fig. 3). In the present study, the base of the Dorsoplanites bed appears at 69 metres in the Knorringfjellet profile and at 21.7 metres in the Janusfjellet profile. The measured and sampled successions from Janusfjellet and Knorringfjellet are calibrated according to the stratigraphic position of the Dorsoplanties marker bed (Fig. 3).

In total, 37 shale samples and three carbonate-seep samples were processed following standard palynlogical preparation methods by Applied Petroleum Technology AS. For tails, see Dalseg (2012). The prepared samples were studied in an optical microscope. Due to poor preservation, many of the specimens could not be identified to species level. In general, the seep samples contain better preserved palynomorphs than the shale samples (Dalseg et al., 2016). Amorphous organic matter (AOM) was also studied under UV-light to identify terrestrially derived AOM and marine AOM.

For each sample, hundreds of palynomorphs and pieces of palynodebris were counted for semiquantitative analysis. The palynological assemblages were split into the following groups: chitineous foraminferal test linings (CFTL), saccate pollen, nonsaccate pollen, spores, dinoflagellate cysts, Tasmanites spp., Leiosphaeridia spp., plant debris, wood particles and amorphous organic matter (AOM), following the systems used by Götz et al. (2008) and Van der Zwan (1990).

To obtain measures of abundance, diversity and similarity of the palynological assemblages, all data were processed 
with Microsoft Excel and PAST (palaeontological statistics; Hammer et al., 2001). Tables with the statistical results (counted specimens, Simpson 1-D index, Shannon $\mathrm{H}$ index and Fisher alpha index) are presented in Dalseg (2012), together with the counts of the various palynofacies groups for each sample.

\section{Dinoflagellate cyst biostratigraphy and stratigraphic correlations}

The stratigraphic distribution and the semiquantitative records of the various dinoflagellate cyst species recovered in the examined sections at Janusfjellet and Knorringfjellet are shown in Figs. 4 and 5, respectively.

The dinoflagellate cyst diversity is generally low, and few stratigraphically age-diagnostic species are encountered in the two studied sections. Similar low-diversity assemblages were described from the BathonianHauterivian succession at Janusfjellet (Århus, 1988). Århus (1988) concluded that the low dinoflagellate cyst diversity in the Middle Oxfordian - Berriasian 'borealis' assemblage makes more detailed biostratigraphic age determinations, and correlations with age-equivalent successions elsewhere in the Arctic areas and Boreal regions, rather difficult.

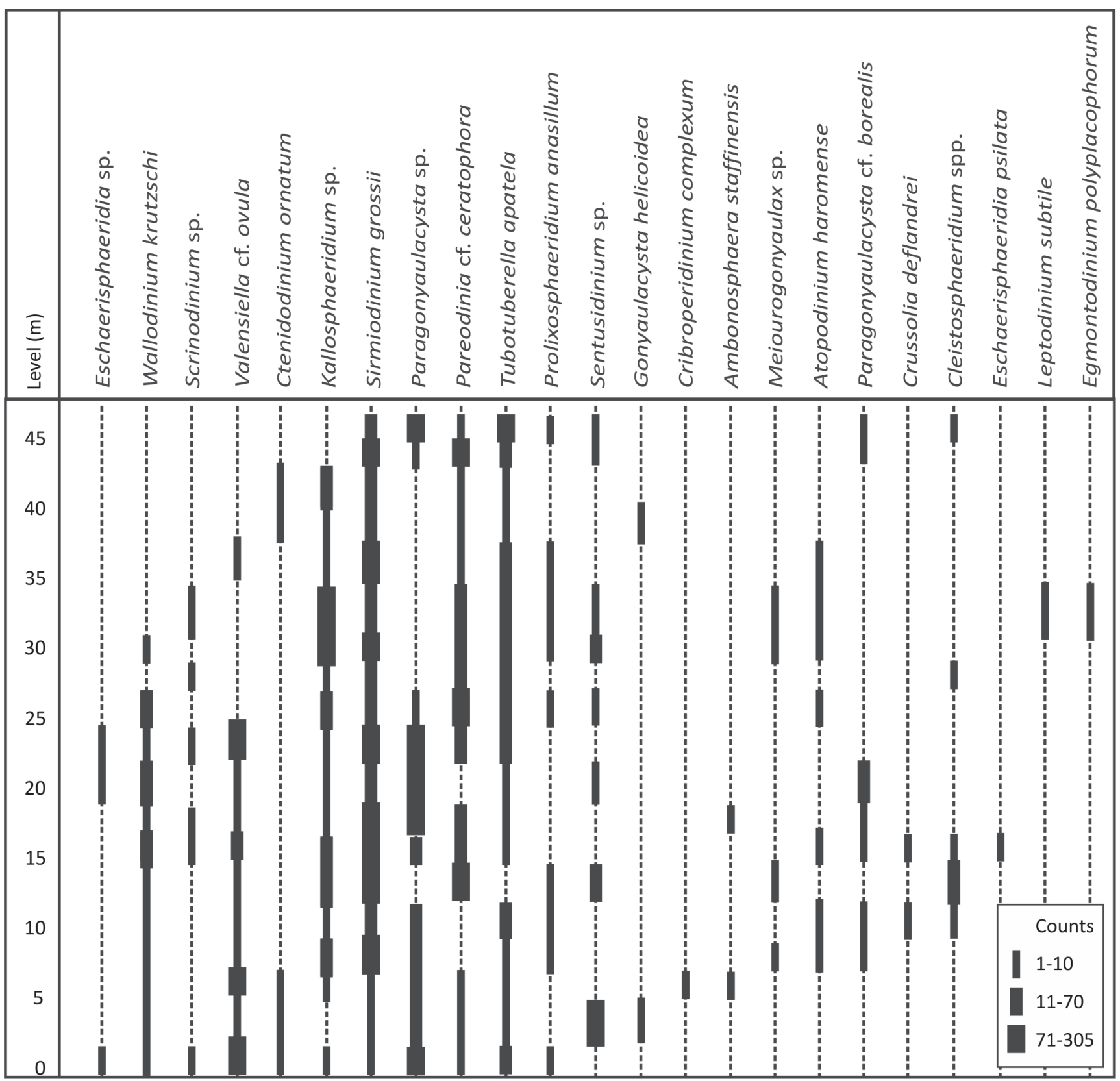

Figure 4. Stratigraphic and semiquantitative distribution of dinoflagellate cyst taxa in the Slottsmøya Member at Janusfjellet, central Spitsbergen. The diagram is based on counts of approximately 300 specimens for most of the samples. 


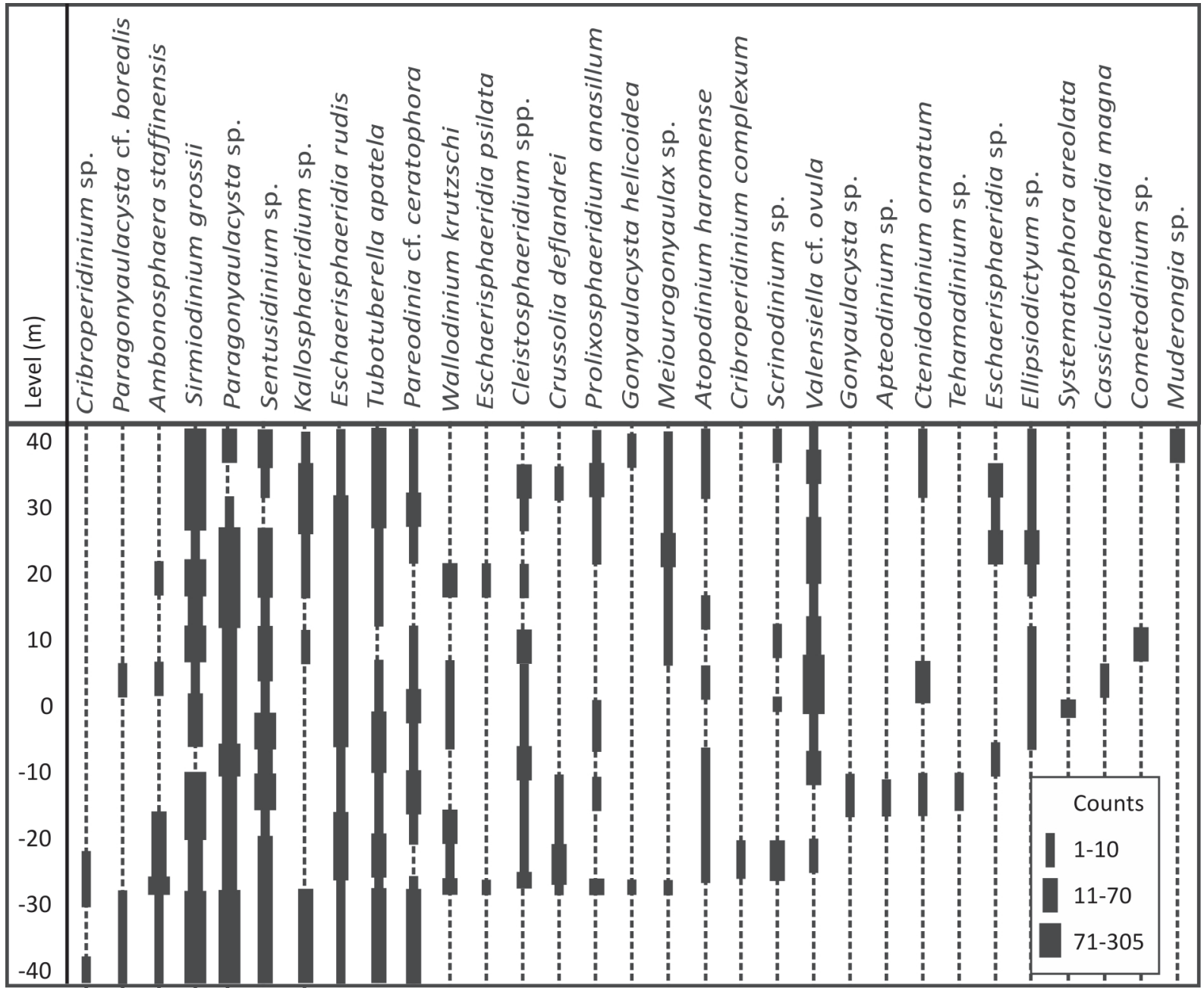

Figure 5. Stratigraphic and semiquantitative distribution of dinoflagellate cyst taxa in the Slottsmøya Member at Knorringfjellet, central Spitsbergen. The diagram is based on counts of approximately 300 specimens for most of the samples.

However, the dinoflagellate cysts offer a possibility for local correlations between the studied Upper Jurassic sections in central Spitsbergen. Two informal assemblage zones have been defined on the basis of dinoflagellate cysts (Fig. 3), as follows:

\section{Zone 1 (Paragonyaulacysta sp., Sirmiodinium grossii zone):}

The lower boundary of Zone 1 is defined by the last abundant occurrence of Valensiella cf. ovalis and the first abundant occurrence of Sirmiodinium grossii. The upper boundary (and base of Zone 2) is defined by the last abundant occurrence of Paragonyaulacysta spp. and the first common occurrence of Tubotuberella apatela and Kallosphaeridium spp.. Zone 1 is also characterised by the highest frequencies of $S$. grossii and Paragonyaulacysta spp..

\section{Zone 2 (Kallosphaeridium sp., Tubotuberella apatela zone):}

The upper boundary of Zone 2 is defined by the last common occurrence of Kallosphaeridium sp.. Zone 2 is also characterised by the highest frequencies of Prolixosphaeridium anasillum and Escharisphaeridia spp. in the Knorringfjellet section.

Zone 1 covers the interval from $6 \mathrm{~m}$ to $23.48 \mathrm{~m}$ in the Janusfjellet section, and from $6 \mathrm{~m}$ to $26 \mathrm{~m}$ in the Knorringfjellet section. Zone 2 covers the interval from $23.48 \mathrm{~m}$ to $33.53 \mathrm{~m}$ in the Janusfiellet section, and from $26 \mathrm{~m}$ to $36 \mathrm{~m}$ in the Knorringfjellet section. The zones are correlated with the bulk organic carbon isotope curve presented in Hammer et al. (2012) (Fig. 3). The curve peaks at $6 \mathrm{~m}$ in both profiles. This corresponds to the base of Zone 1 established in the present study. The next bulk organic carbon isotope peak in the Knorringfellet section occurs at $26 \mathrm{~m}$, which corresponds to the boundary between Zones 1 and 2 in the succession. The next bulk organic carbon peak in the Janusfjellet section occurs at $23.48 \mathrm{~m}$, which 
corresponds to the peak at $26 \mathrm{~m}$ in the Knorringfjellet section.

The lower boundary of the dinoflagellate cyst Zone 1 occurs at $6 \mathrm{~m}$ in both profiles. This corresponds to the boundary between foraminiferal zones F4 and F5 of Nagy \& Basov (1998) and Hjálmarsdóttir et al. (2012), and is dated as earliest Middle Volgian. The boundary between both the dinoflagellate cyst zones in the Knorringfjellet profile, and between foraminiferal zones F5 and F6, occurs at approximately 26 metres and is within the latest Middle Volgian. The upper boundary of dinoflagellate cyst Zone 2 occurs at $36 \mathrm{~m}$ in the Knorringfjellet section and at $33.53 \mathrm{~m}$ in the Janusfellet section. This corresponds to the middle part of foraminifera zone F6 and is Late Volgian in age (Nagy \& Basov, 1998; Hjálmarsdóttir et al., 2012).

A significant increase in algae Leosphaeridia spp. at 45.62 $\mathrm{m}$ in the Janusfjellet section (Fig. 6) may correlate with the Leiosphaeridia spp. bloom known from the VolgianRyazanian in the Barents Sea region (Smelror et al., 2002; Bremer et al., 2004; Smelror \& Dypvik, 2005, 2006; Dypvik et al., 2006). This Leiosphaeridia spp. bloom is believed to have been induced by the Mjølnir meteorite impact in the western Barents Shelf at that time.

Based on foraminifera and ammonite biostratigraphy, the Slottsmøya Member is dated to Volgian and Ryazanian age (Nagy \& Basov, 1998; Wierzbowski et al., 2011). The biozones are dated to be of Volgian and Ryazanian age. A precise positioning of the Volgian-Ryazanian boundary, however, is not determined due to a significant reduction in sedimentation rate and poor exposure at this level (Hammer et al., 2012). If the Leiosphaerdia spp. bloom at $45.62 \mathrm{~m}$ in the present study also has been induced by the Mjølnir meteorite impact, the Volgian-Ryazanian boundary can be close to this level. The Leiosphaeridia spp. bloom in the present study appears to be the same as the Leiosphaeridia spp. bloom in the Agardhfjellet Formation at Janusfiellet presented in Dypvik et al. (2006) and which was recorded $4 \mathrm{~m}$ below the Myklegardfjellet Bed.

In Spitsbergen, the stratigraphical interval from the uppermost part of the Upper Volgian (Taimyrensis Zone) to Lower Ryazanian (Kochi Zone) is poor in ammonites. Wierzbowski et al. (2011) suggested that this may be attributed to non-deposition at this time, or may be due to erosion by tsunami waves from the Mjølnir meteorite impact.

On the Barents Shelf, the strata influenced by the impact are described as the Sindre Bed (Dypvik et al., 2004). The ammonite Borealites is recorded in borehole 7430/10-U01 from the southern Barents Sea, located $30 \mathrm{~km}$ northeast of the Mjølnir Crater (Smelror et al., 2002; Wierzbowski et al., 2011). Borealites was found directly above the Sindre Bed at $44.10 \mathrm{~m}$ in borehole $7430 / 10-\mathrm{U}-01$, and precisely dates the impact. Borealites is indicative of the Kochi Zone or the Maynci-Sibiricus Zone (Lower Ryazanian;
Wierzbowski et al., 2011). In central Spitsbergen no ammonites representing the Maynci-Sibiricus Zone are found, but some poorly represented species belonging to the Kochi Zone have been recovered (Wierzbowski et al., 2011). Hence, the Leiosphaeridia spp. bloom recorded at $45.62 \mathrm{~m}$ in the present study appears also to correlate with the Lower Ryanzanian ammonite zones.

\section{Palynofacies and depositional environment}

In this study, in addition to the sediments and fossil assemblages, palynofacies analysis (Tyson 1993, 1995) is used to interpret the depositional environment and relative sea-level changes in the studied successions. The palynofacies recorded in the samples have been grouped into terrestrial and marine fractions (Fig. 6).

The main factors controlling the distribution of the terrestrial (allochthonous) and the marine (relatively autochthonous) organic particles, taken into consideration in this study, are distance to land, organic productivity, both terrestrial and marine, water currents and degree of biodegradation. In addition, salinity and hydrographic conditions, such as temperature and water circulation, are controlling factors.

The composition of the palynological material in the Janusfiellet and the Knorringfjellet profiles shows quantitative and qualitative differences (Fig. 6). Significantly higher amounts of amorphous organic matter $(\mathrm{AOM})$ and higher amounts of chitinous foraminifera test linings (CFTL), Leiosphaeridia spp., Tasmanites spp. and spores are recorded in the Janusfiellet profile, while the Knorringfjellet sections reveal higher amounts of plant debris and woody particles. The dinoflagellate cyst assemblages also show better preservation and higher abundances and diversities in the Knorringfjellet section than in the Janusfjellet section. The nonsaccate pollen and saccate pollen are the only palynofacies groups which occur in similar abundances in the two profiles.

In overall character, the various groups of organic debris show similar increasing and decreasing trends and shifts throughout both profiles (Fig. 6). This suggests that the palynofacies compositions mirror the same trends of relative sea-level changes (Fig. 7). The organic contents in both profiles indicate an outer shelf/deepmarine environment. This is indicated by the high amounts of AOM, Tasmanites spp. and Leiosphaeridia spp. in the Janusfjellet profile and by the high diversities and abundances of the dinoflagellate cysts in the Knorringfjellet profile.

Dypvik et al. (1991a) found an increase in thickness variations of the shales relative to the sandstones towards 


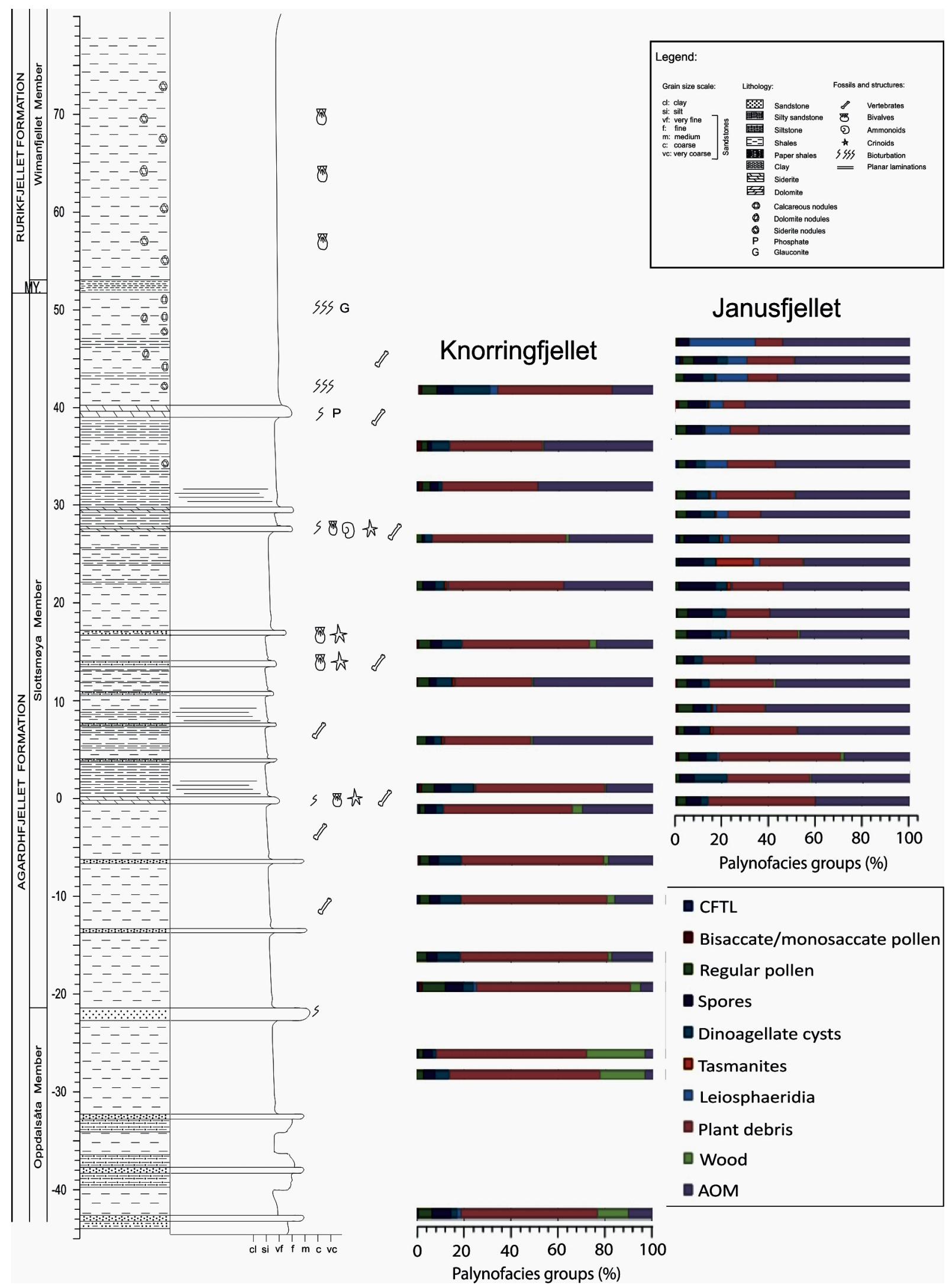

Figure 6. Changes in the palynofacies components through the Knorringfjellet and the Janusfjellet profiles. The general lithological log is modified from Collignon (2011). Abbreviations: AOM - amorphous organic matter; CFTL - Chitinous Foraminferal Test Linings. 
the east in the Agardhfjellet Formation. They attributed the eastward thickness increase of the shale as being a result of tectonic movements during the Tertiary. Considering the occurrence of AOM in tectonic decollement zones (Hansley \& Spirakis, 1992), this could explain the higher proportion of plant debris in Knorringfjellet, but not the higher abundances and diversities among the dinoflagellate cysts.

The macro- and microfossil biostratigraphy, TOCdata and organic isotope data suggest that there are no stratigraphic offsets between the two studied sections (Wierzbowski et al., 2011; Hammer et al., 2012). Further, the similarity between carbon isotope curves indicates comparable sedimentation rates, and there is no evidence of any differences in thermal or diagenetic conditions between the two sections (Hammer et al., 2012).

The higher amounts of AOM, Leiospaheridia and Tasmanites in Janusfjellet could point towards a lower oxygen content in this area. Local differences in oxygen levels caused by differences in vertical water circulation can be a consequence of local barriers (Dypvik et al., 1991b). The presence of cold seep deposits at both Janusfjellet and Knorringfjellet, however, does not indicate such differences. Furthermore, the seep microfacies suggest similar environmental conditions (Hryniewicz et al., 2012).

The palynofacies contents in the shale from the stratigraphic levels containing the seep deposits (i.e., at around $40 \mathrm{~m}$ to $45 \mathrm{~m}$; Fig. 2) show similar compositional differences as in the palynofacies from the shale below (Fig. 6). This could indicate that the differences in the palynological assemblages between the two profiles do not relate to differences in the oxygen content of the bottom water. Deposits indicating a barrier formation, such as marked thickness changes or facies changes, are not observed. If we assume a more offshore environment in Janusfiellet compared to Knorringfiellet, this should have been evident by the presence of more offshore palynofacies proxies, such as lower amounts of spores and higher diversities and amounts of dinoflagellate cysts in Janusfjellet. In this study, however, the opposite is the case.

An explanation for the higher amount of AOM in the Janusfellet profile can be that, if Janusfjellet is more proximal than Knorringfiellet, the more robust terrestrial particles have been transported farther out on the shelf, and thereby the terrestrial particles in Janusfiellet have been more easily exposed to degradation into AOM. The higher degree of degradation of plant debris in more proximal areas can also be indicated by the trends of increasing and decreasing wood, $\mathrm{AOM}$ and plant debris contents through the studied sections.

In strata where the total percentages of the terrestrial input increase due to a sea-level regression, the AOM is also increasing, while the plant debris tends to decrease or show only small variations. The possible locations of the two areas relative to the shoreline might also explain the generally higher amounts of spores in the Janusfjellet profile. A counterargument to this is that since the localities are relatively close to each other compared to the distance to the NE Greenland shore, such significant differences may have other explanations. The presence of an island closer to the Janusfjellet area than to the Knorringfjellet area is also a possibility, and could be an explanation for the hypothesis of one locality being more proximal than the other.

The most prominent differences between the two profiles are the abundances and diversities among the dinoflagellate cysts, and the amounts of AOM and plant debris (Fig. 6). The low dinoflagellate cyst content and the high AOM content in the Janusfjellet profile could point towards a higher degree of degradation of marine algae into $\mathrm{AOM}$ in this area. However, as previously mentioned, the majority of the AOM is composed of terrestrial material in both profiles. This contradicts the suggestion that there could be a link between the diversities among the dinoflagellate cysts and the amounts of $\mathrm{AOM}$ and plant debris.

The higher diversities and abundances among the dinoflagellate cysts in the Knorringfiellet profile may be a consequence of a possible more distal location. Different currents influencing the algal components by transport, either in the water column or by local sea-floor currents, can thus have been present in Knorringfjellet. Tasmanites is commonly most abundant in near shore/low oxygen environments (Revill et al., 1994). The significantly higher contents of this algal group in the Janusfjellet section than in the Knorringfiellet section can also be ascribed to a possible more proximal location of Janusfjellet. The abundance of Leiosphaeridia spp. seems to increase with transgression of the sea level. This does not, however, support the hypothesis that Janusfjellet is more proximal to the shore than Knorringfjellet.

No descriptions are found of other fossil groups from Janusfellet and Knorringfjellet which either indicate the same differences in diversities or point to a different mode of preservation (Wierzbowski et al., 2011; Hryniewicz et al., 2012; Hurum et al., 2012). Larger pelagic animals, such as marine reptiles and ammonites described from the Slottsmøya Member, may not be influenced in the same way as microscopic algae, if the difference in dinoflagellate cysts diversities was due to water currents. The carcasses of the pelagic animals were for some indeterminate amount of time exposed to degradation on the sea floor before burial (Hurum et al., 2012). If the differences in palynological assemblages were influenced by oxygen contents near the water-sediment transition, these animals might show different modes of preservation in Knorringfjellet and in Janusfjellet. 


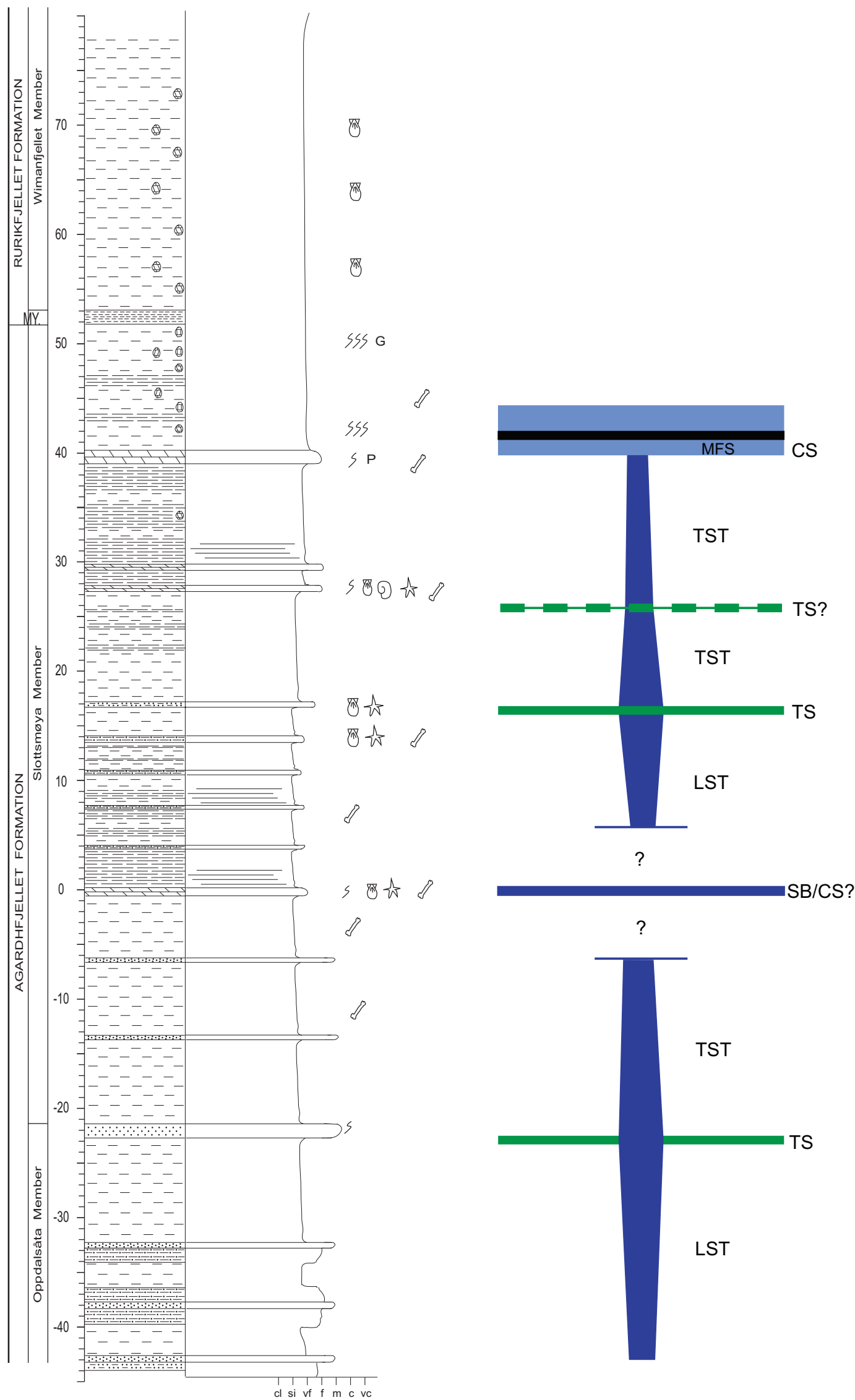

Figure 7. Sequence-stratigraphic model for the upper Oppdalsåta Member and the Slottsmøya Member. The lithological log is from Janusfjellet (Collignon, 2011). The sequence-stratigraphic model type is based on the sequence-stratigraphic model presented in Collignon (2011). The different levels investigated from the Janusfjellet and the Knorringfjellet profiles in the present study are placed approximately in relation to the lithological log by Collignon. Abbreviations: CS - Condensed Section, MFS - Maximum Flooding Surface; LST - Lowstand System Tract; TST - Transgressive System Tract; TS - Transgressive Surface; SB - Sequence Boundary. 


\section{Palynofacies and sequence stratigraphy}

Palynofacies can be used as an aid in sequence stratigraphy. Palynodebris behave as sedimentary particles and different palynofacies assemblages are typically found in the different system tracts (Batten \& Stead, 2005). Lowstand system tracts (LST) are generally indicated by numerous spores and pollen grains which are not well preserved, indicating only partial oxidation, and large phytoclasts (Batten \& Stead, 2005). The pollen/ spore ratio tends to decrease, and black woody detritus is also a common component of such palynofacies. A reduction in the content of $\mathrm{AOM}$ is often accompanied by an increase in the content of terrestrially derived wood and plant debris (Batten \& Stead, 2005). In the present study, however, the AOM is dominated by terrestrially derived material. LST are also indentified by lower amounts and diversities among dinoflagellate cysts and higher amounts of Leiosphaeridia spp. and Tasmanites spp. (Revill et al., 1994; Batten \& Stead, 2005).

Transgressive system tracts (TST) are generally indicated by palynofacies where dinoflagellate cysts are more important components, whereas spores and phytoclasts are smaller and less varied (Batten \& Stead, 2005). Terrestrial organic matter is also generally less common in TST (Brizuela et al., 2007).

Highstand system tracts (HST) typically contain a significant component of dinoflagellate cysts as the most numerous of the palynomorph components (Batten \& Stead, 2005). This is normally observed in combination with a decrease in terrestrially derived debris (Brizuela et al., 2007).

Maximum flooding surfaces (MFS) represent the maximum water depth, and are usually associated with a condensed section (CS) (Van Wagoner et al., 1988). A condensed section is normally recognised by an abundance of fossils and good preservation due to lowering of the oxygen level at the water sedimentinterface (Kitamura, 1998). Degradation of marine algae and terrestrially derived plant debris into AOM can also occur (Prasad et al., 2007). The greater robustness of thick-walled palynomorphs makes them less exposed to degradation and transportation along the sea floor. This might be the reason why an increase in the percentages of Tasmanites, regular pollen and spores is commonly observed together with more offshore proxies.

Changes in the palynofacies through the profiles are correlated with the bulk organic carbon isotope values and the total organic carbon (TOC) values presented in Hammer et al. (2012) (Fig. 3), and shifts in the values are correlated with changes in the palynological assemblages. A very general correspondence between the total organic carbon isotope values and sea-level changes were noted in the study by Hammer et al. (2012). In the present study, a similar trend of marine transgression is shown through both profiles (Fig. 7), but the palynofacies do not generally show any unambiguous indications of the different system tracts.

Collignon (2011) proposed a depositional sequencestratigraphic model for the Slottsmøya Member based on sedimentology and geochemistry. This model, in addition to the zones established in the present study, is here used for correlations. The large quantities of AOM and plant debris in the samples marginalize the counts for the other palynodebris groups, and they are therefore of limited reliability. Due to this, sudden deviations in these groups are not taken into account unless other factors also show the same trend, e.g., TOC-values, bulk organic carbon isotope values (Hammer et al., 2012) and lithological logs (Collignon, 2011).

Strata from $-43 \mathrm{~m}$ to $27 \mathrm{~m}$ in the Knorringfellet profile are dominated by plant debris and wood. The interval from $-43 \mathrm{~m}$ to $-21 \mathrm{~m}$ represents the upper part of the Oppdalsåta Member (Figs. 6, 7). The lowest percentages of $\mathrm{AOM}$ and the highest percentages of wood occur in this part of the profile. The diversity among the dinoflagellate cysts is also significantly lower in the lowermost samples, from $-43 \mathrm{~m}$ to $-29 \mathrm{~m}$, than in the rest of the section. These strata consist of silt and fine sand, and represent a lowstand interval with a higher energy regime (Dypvik et al., 1991a, 1991b; Collignon, 2011).

The first marked change in the palynofacies occurs at $-21 \mathrm{~m}$. This level also represents the transition from the Oppdalsåta Member to the Slottsmøya Member (Figs. 7, 8; Collignon, 2011). A significant decrease in wood content is recorded together with increases in saccate pollen, nonsaccate pollen and spores from around $21 \mathrm{~m}$. Increases in AOM and in abundance of dinoflagellate cysts occur at -17 metres. The content of pollen, spores, Leiosphaeridia spp. and wood decreases at around $17 \mathrm{~m}$. The changes in this interval may indicate a transgressive surface (TS) at $-21 \mathrm{~m}$ (Fig. 8). The TOC values peak at $-21 \mathrm{~m}$, which correlates with the palynological changes at the same level. The bulk organic carbon isotope curve also shows a small change at $-17 \mathrm{~m}$ (Fig. 3). A transgressive surface was also interpreted at this level by Collignon (2011).

The percentages of the palynological assemblages remain stable from $-17 \mathrm{~m}$ to $-7 \mathrm{~m}$ in the Knorringfjellet profile. This interval is interpreted as a TST (Fig. 8). This part of the profile has no palynological samples comparable to those from Janusfellet. An increase in AOM content occurs at $-2 \mathrm{~m}$ in the Knorringfellet section, and a decrease in dinoflagellate cyst content is shown at the same level. The percentages of the palynofacies assemblages at $-1.31 \mathrm{~m}$ in the Janusfiellet profile are similar to those at $-2 \mathrm{~m}$ in the Knorringfiellet section.

Collignon (2011) proposed a MFS at $-5 \mathrm{~m}$ with a following HST and sequence boundary (SB) at $-2 \mathrm{~m}$. Due 

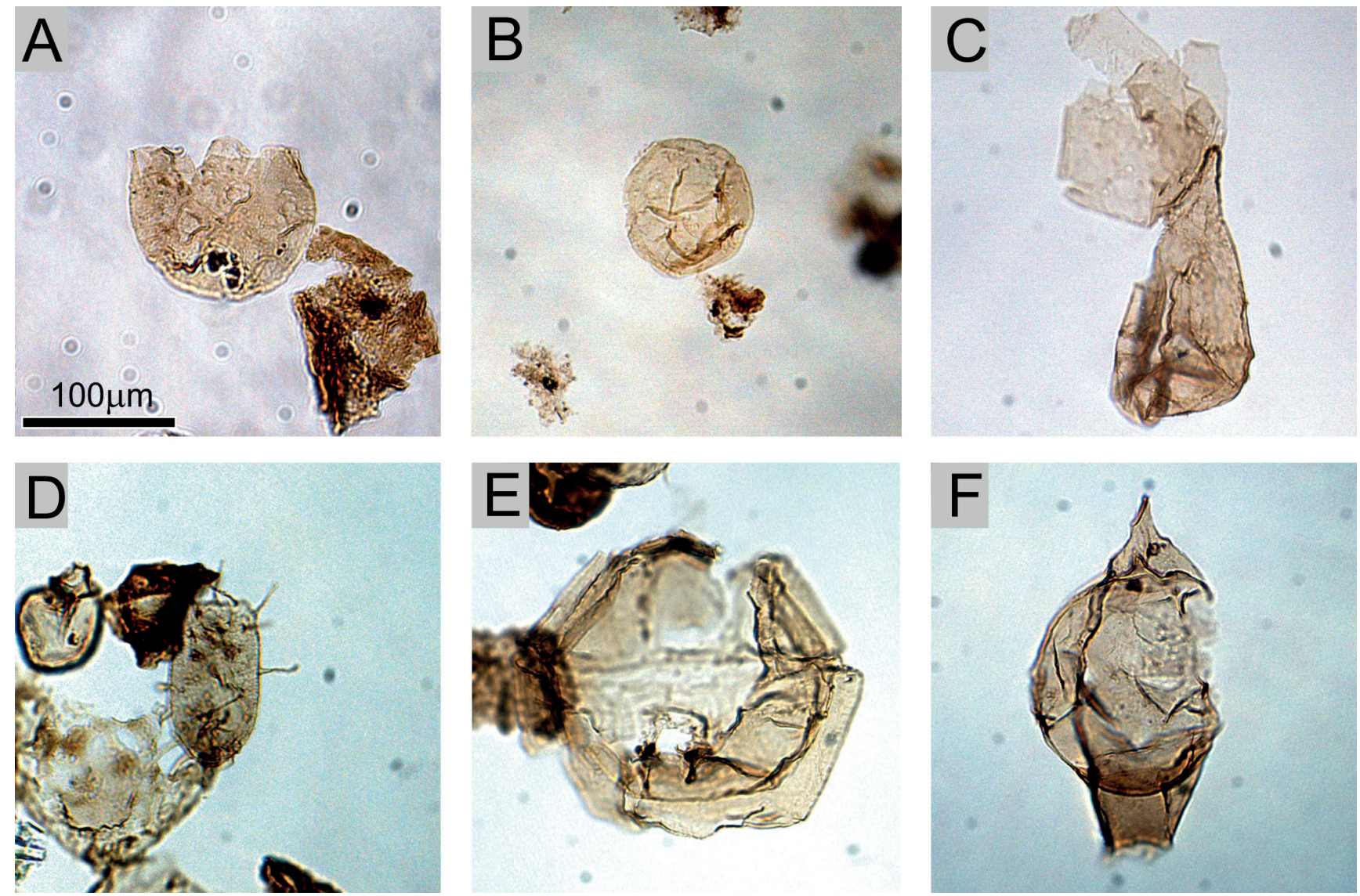

Figure 8. Marine microplankton from the Janusfjellet Formation, Spitsbergen. Samples are stored in the paleontological collection (PMO) at the Natural History Museum in Oslo. The PMO sample numbers and slide coordinates are shown in parentheses; EF - England Finder coordinates. Scale bar represents $100 \mu \mathrm{m}$. (A) Kallosphaeridium sp. (Locality Knorringfjellet, PMO 221.517A, E53/2); (B) Leiosphaeridia sp. (Locality Janusfjellet, PMO 221.552A, G58/3); (C) Paragonyaulacysta sp. (Seep loc. 2007-1, PMO 221.553C, L42/3); (D) Prolixosphaeridium anasillum (Seep loc. 2007-01 PMO 221.553C, F51/1); (E) Sirmiodinium grossii (Seep loc. 2007-01 PMO 221.553C, E44/2); (F) Tubotuberella apatela (Seep loc. 2007-01 PMO 221.553C, M37/4).

to the longer sampling intervals in the Knorringfjellet profile, indications of both the MFS and the HST may have been omitted from the palynological sampling. The palynofacies assemblages at $-2 \mathrm{~m}$ and $-1.31 \mathrm{~m}$ are difficult to interpret, as the bulk organic carbon isotope curve and the TOC values do not show any changes at this level. The diversities among the dinoflaggelate cysts also show only insignificant changes at this level. The palynofacies assemblages at -2 and $-1.31 \mathrm{~m}$ in the two profiles point towards a lowstand. Because this is not supported by any other datasets, no systems tract is proposed for this interval (-7 $\mathrm{m}$ to $-1.31 \mathrm{~m}$; Fig.7).

The bulk organic carbon isotope curve peaks at $0 \mathrm{~m}$ in the Janusfellet profile in the study by Hammer et al. (2012). At $0 \mathrm{~m}$ in the Knorringfjellet profile, percentages of AOM are significantly lower than in the immediate underlying and overlying levels. The same is shown for the 'plant debris' content at $0.77 \mathrm{~m}$ in the Janusfjellet profile. The dinoflagellate cyst contents in both profiles are significantly higher than in immediate underlying and overlying samples at these levels. The first Tasmanites occurrence is recorded at $0 \mathrm{~m}$ in the Knorringfjellet profile.
The observations point towards a condensed section (CS) at $0.77 \mathrm{~m}$ in the Janusfellet profile and at $0 \mathrm{~m}$ in the Knorringfjellet profile (Fig. 7). A sideritic bed is present at $0 \mathrm{~m}$ in the sedimentological log presented by Collignon (2011). The palynofacies contents and the sideritic bed at this level strongly point towards a condensed section. Collignon (2011) has interpreted this level as part of a TST overlying a SB.

An increase in plant debris and decrease in $A O M$ is recorded from $3.95 \mathrm{~m}$ in the Janusfjellet profile, but the percentages are deviating from the immediate underlying and overlying levels. Neither Collignon (2011) nor Hammer et al. (2012) have suggested any changes at 3.95 $\mathrm{m}$. The different percentages of AOM and plant debris at $3.95 \mathrm{~m}$ are therefore difficult to interpret.

An increase in $\mathrm{AOM}$ and decrease in 'plant debris' is recorded from $6 \mathrm{~m}$ in the Knorringfjellet section. At 6.03 $\mathrm{m}$ in the Janusfiellet profile the AOM is dominant, similar to the corresponding level in Knorringfjellet. The first appearance of Tasmanites is recorded at 6.03 metres in the Janusfjellet profile, and a small increase is recorded 
at $6 \mathrm{~m}$ in the Knorringfjellet profile. The percentages of AOM and 'plant debris' remains are stable from 6 to $11 \mathrm{~m}$ in the Knorringfjellet profile and from $6.03 \mathrm{~m}$ to $13.75 \mathrm{~m}$ in the Janusfjellet profile. The dinoflagellate cyst content decreases in this interval in both profiles. These palynofacies assemblages point towards a LST in this interval (Fig. 7). Changes in the bulk organic carbon isotope values and the TOC values (Fig. 3; Hammer et al., 2012) are also shown at these levels. A lowering of the sea level was also interpreted by Hammer et al. (2012) near the negative isotope excursion at $6 \mathrm{~m}$.

Collignon (2011) suggested the presence of a flooding surface at $6 \mathrm{~m}$. However, the stable percentages of all the palynofacies groups from 6 to $11 \mathrm{~m}$ in Knorringfjellet and from 6.03 to $13.75 \mathrm{~m}$ in Janusfellet contradict this interpretation. The lower boundary of zone 1 occurs at 6 $\mathrm{m}$ in both profiles (Fig 3).

A change in the palynological assemblages occurs at 16 $\mathrm{m}$ in the Knorringfjellet profile and at $15.77 \mathrm{~m}$ in the Janusfjellet profile. In both profiles the AOM decreases and the amount of plant debris and wood increase. The percentages deviate from the immediate underlying and overlying levels. Increases in dinoflagellate cyst contents occur at this level in both profiles, deviating from the immediate underlying and overlying levels. There is also a shift in the TOC curve at this level, suggesting the presence of a transgressive surface (TS) (Fig. 7).

The interval from $15.77 \mathrm{~m}$ to $26.07 \mathrm{~m}$ in the Janusfjellet profile is characterised by relatively high percentages of dinoflagellate cysts, spores and Tasmanites spp. Relatively low percentages of plant debris and wood are also shown from $17.95 \mathrm{~m}$ in this profile. At $21 \mathrm{~m}$ in the Knorringefjellet profile low percentages of plant debris, dinoflagellate cysts and regular pollen are recorded. At the same level in this profile, the contents of Tasmanites spp. and spores increase. These observations can indicate a TST from 16 to $26 \mathrm{~m}$ (Fig. 7).

At $26 \mathrm{~m}$ in the Knorringfjellet profile an increase in the contents of plant debris and wood are observed. At $23.48 \mathrm{~m}$ in the Janusfjellet profile, a decrease in AOM and the plant debris content deviates from the immediate overlying and underlying levels (Fig. 7). The Tasmanites spp. content peaks at $23.48 \mathrm{~m}$ in the Janusfellet profile, showing large deviations from the immediate underlying and overlying levels. The Leiosphaeridia spp. algae show an increase at this level, which remains stable until $33.53 \mathrm{~m}$. The TOC values also change at this level. The bulk organic carbon isotope curves change at 26 $\mathrm{m}$ in the Knorringfjellet profile and at $23.48 \mathrm{~m}$ in the Janusfellet profile (Fig. 3; Hammer et al., 2012). The shift in palynofacies points towards a TS also at this level (as interpreted at $16 \mathrm{~m} / 15.77 \mathrm{~m}$; Fig 8).

A TS was proposed at $28 \mathrm{~m}$ by Collignon (2011). A HST might be present instead of the upper part of the TST interpreted from 16 to $26 \mathrm{~m}$, which would imply a TS at $26 \mathrm{~m}$. A transgressive surface at approximately $26 \mathrm{~m}$ is coeval with the boundary between the dinoflagellate zones 1 and 2 at $26 \mathrm{~m}$ in the Knorringfjellet profile and at $23.48 \mathrm{~m}$ in the Janusfjellet profile.

From $30 \mathrm{~m}$ to $39.52 \mathrm{~m}$ in the Janusfiellet profile the plant debris decrease and the AOM increase. The same trend is shown from $31 \mathrm{~m}$ to $36 \mathrm{~m}$ in the Knorringfjellet profile. The total content of AOM and 'plant debris' remains stable in both profiles. The CFTL and Leiosphaeridia spp. contents generally increase in this interval in the Janusfjellet profile. This interval in both the Janusfellet and the Knorringfjellet profiles is interpreted as a further TST (Fig. 7). The same interpretation was also suggested in Collignon (2011).

Collignon (2011) also proposed a MFS at $42 \mathrm{~m}$. The TOC curve peaks at the same level. The AOM content decreases and the plant debris content increases at $41 \mathrm{~m}$ in the Knorringfjellet profile and at $42 \mathrm{~m}$ in the Janusfellet profile. The total content of plant debris and AOM decreases in both profiles. An increasing abundance of spores, dinoflagellate cysts and Leiosphaeridia spp. is shown in both profiles. A sideritic bed is also present at $40 \mathrm{~m}$ (Collignon, 2011), which indicates a CS at this level (Fig. 8; Nagy et al., 2009; Collignon, 2011). A MFS at $42 \mathrm{~m}$ and a CS from $41 \mathrm{~m}$ to $45.62 \mathrm{~m}$ is also interpreted in the present study (Fig. 7). The percentages of the palynomorph contents remain generally stable up to the uppermost sampled level at $45.62 \mathrm{~m}$ in the Janusfiellet profile. At this level a significant increase in Leiosphaeridia spp. and decrease in dinoflagellate cyst and spore contents are recorded. There are no comparable palynological samples above $41 \mathrm{~m}$ in the Knorringfjellet profile. Interpretations of the changes above this level are therefore more uncertain. The bulk organic carbon isotope curve shifts at $41 \mathrm{~m}$ in both profiles (Fig. 3; Hammer et al., 2012). The bottom of a HST is interpreted at $45.62 \mathrm{~m}$. This is based on the changes in the palynofacies and also on the HST following the MST (see also Collignon, 2011). A coarsening interval in the top of the Slottmøya Member indicates a subsequent regression of the relative sea level (Dypvik et al., 1992).

Other correlations between some of the palynofacies groups are not so obvious. High spore and regular pollen contents, and to some degree a high Tasmanites spp. content, correspond to high contents of dinoflagellate cysts. This may be due to the observed thicker walls of regular pollen, spores and Tasmanites spp. and thus a higher robustness, as previously mentioned. These palynomorphs could therefore have been transported over relatively long distances in the water masses and along the sea floor. 


\section{Conclusions}

The dinoflagellate cyst assemblages recovered from the upper Oppdalsaita Member and the Slottsmøya Member (Agardhfjellet Formation) at Janusfjellet and Knorringsfjellet in central Spitsbergen comprise mostly long-ranging species of limited biostratigraphical importance (Fig. 8).

The dinoflagellate cysts can, however, be used for intraformational correlations, and two informal zones have been defined within and correlated between the studied Upper Volgian-Ryazanian sections. Based on the recorded Leiosphaeridia spp. bloom at $45.62 \mathrm{~m}$ in the Janusfjellet section, the Volgian-Ryazanian boundary is proposed to occur at approximately $45 \mathrm{~m}$ in the Slottsmøya Member. The Leiospaheridia spp. bloom is also correlated with the Leiosphaerida spp. bloom presented in Dypvik et al. (2006), and places this level in the Janusfjellet section $4 \mathrm{~m}$ below the Myklegardfjellet Bed (Rurikfjellet Formation).

Significant differences in the composition of the palynofacies components in the Janusfjellet and Knorringfjellet sections were observed. Differences in abundances and diversities among the dinoflagellate cysts between the investigated profiles are also evident. Several explanations are considered, but no specific explanation is regarded as definitive.

Sequence-stratigraphic analysis carried out in the present study shows good correlation between changes in the palynofacies and the bulk total organic carbon isotope values and TOC values presented in Hammer et al. (2012), as well as with the dinoflagellate cyst zones established in the present study. A general sea-level transgression through the Janusfjellet and the Knorringfjellet profiles is proposed based on the palynofacies analysis, the bulk total organic carbon isotope values and the TOC values. This interpretation is also in accordance with the sequence stratigraphic model proposed by Collignon (2011).

Acknowledgements. The sample material used in this study was collected by Øyvind Hammer and Hans Arne Nakrem during the palaeontological expeditions organised by the Natural History Museum, University of Oslo in 2008 and 2009. Fieldwork in Svalbard (2007-2010) was financed by the Norwegian Research Council, Norwegian Petroleum Directorate, Spitsbergen Travel, ExxonMobil, Fugro, Statoil, OMV, Powercontrols and Hydro, and by grants nos. EC0425-09 and EC043509 from the National Geographic Society. The authors are grateful to all the volunteers and students who have contributed weeks of fieldwork for free on the project.

\section{References}

Bailey, D.A. 1993: Selected Cribroperidinium species (Dinophyceae) from the Kimmeridgian and Volgian of northwest Europe. Journal of Micropalaeontology 12, 219-225.

Batten, D.J. \& Stead, D.T. 2005: Palynofacies Analysis and its Stratigraphic Application. In Koutsoukos, E.A.M. (ed.): Applied Stratigraphy, Springer, Netherlands, pp. 203-226.

Bjærke, T. 1980: Mesozoic Palynology of Svalbard V. Dinoflagellates from the Agardhfjellet Member (Middle and Upper Jurassic) in Spitsbergen. Norsk Polarinstitutt Skrifter 172, 145-167.

Bjærke, T., Edwards, M.B. \& Thusu, B. 1976: Microplankton from the Janusfjellet subgroup (Jurassic- Lower Cretaceous) at Agardfjellet, Spitsbergen. A preliminary report. Norsk Polarinstitutt Årbok 1974, 63-68.

Bremer, G.M.A., Smelror, M, Nagy, J. \& Vigran, J.O. 2004: Biotic responses to the Mjølnir meteorite impact, Barents Sea: Evidence from a core drilled within the crater. In Dypvik, H., Burcell, M. \& Claeys, P. (eds.): Cratering in Marine Environments and on Ice, Springer-Verlag, Berlin, Heidelberg, pp. 21-38.

Brizuela, R.R., Marenssi, S., Barreda, V. \& Santillana, S. 2007: Palynofacial approach across the Cretaceous- Paleogene boundary in Marambio (Seymor) Island, Antarctic peninsula. Revista de la Asociación Geológica Argentina 62, 236-241.

Collignon, M. 2011: Sedimentological analysis of the Slottsmøya Member, Agardhfjellet Formation (Late Jurassic-Early Cretaceous) in the Janusfjellet area, Spitsbergen. Master Thesis, University of Oslo, 31 pp.

Dallmann, W.K. (ed.) 1991: Lithostratigraphic Lexicon of Svalbard, Norsk Polarinstitutt, Tromsø, 318 pp.

Dalseg, T.S. 2012: Palynological studies of the upper Oppdalsåta Member and the Slottsmøya Member (Agardhfjellet Formation), Upper Jurassic-Lower Cretaceous in Janusfjellet and Knorringfjellet, Central Spitsbergen. Master Thesis, University of Oslo, 107 pp.

Dalseg, T.S., Nakrem, H.A. \& Smelror, M. 2016: Organic-walled microfossils and palynodebris in cold seep carbonate deposits: The Upper Jurassic-Lower Cretaceous Agardhfjellet Formation on Svalbard (Arctic Norway). Norwegian Journal of Geology 96, 1-12. doi: http://dx.doi.org/10.17850/njg96-2-01.

Dypvik, H., Nagy, J., Eikeland, T.A., Backer-Owe, K., Andresen, A., Haremo, P., Bjærke, T., Johansen, H. \& Elverhøi, A. 1991a: The Janusfjellet Subgroup (Bathonian \& Hauterivian) on central Spitsbergen: A revised lithostratigraphy. Polar Research 9, 21-43.

Dypvik, H., Eikeland, T.A., Backer-Owe, K. \& Johansen, H. 1991b: Depositional conditions of the Bathonian to Hauterivian Janusfjellet Subgroup, Spitsbergen. Sedimentary Geology 72, 55-78.

Dypvik, H., Nagy, J. \& Krinsley, D.H. 1992: Origin of the Myklegardfjellet Bed, a basal Cretaceous marker on Spitsbergen. Polar Research 11, 21-31.

Dypvik, H., Mørk, A., Smelror, M., Sandbakken, P.T., Tsikalas, F., Vigran, J.O., Bremer, G.M.A., Nagy, J., Gabrielsen, R.H., Faleide, J.I., Bahiru, G.M. \& Weiss, H.M. 2004: Impact breccia and ejecta from the Mjølnir crater in the Barents Sea - The Ragnarok Formation and Sindre Bed. Norwegian Journal of Geology 84, 143-167.

Dypvik, H., Smelror, M., Sandbakken, P.T., Salvigsen, O. \& Kalleson, E. 2006: Traces of the marine Mjølnir impact event. Palaeogeography, Palaeoclimatology, Palaeoecology 241, 621-636.

Götz, A.E., Feist-Burkhardt, S. \& Ruckwied, K. 2008: Palynofacies and sea-level changes in the Upper Cretaceous of the Vocontian Basin, southeast France. Cretaceous Research 29, 1047-1057.

Hammer, Ø., Harper, D.A.T. \& Ryan, P.D. 2001: PAST: Palaeontological Statistics Software Package for Education and Data Analysis. Palaeontologia Electronica 4, 9 pp.

Hammer, Ø., Nakrem, H.A., Little, C.T.S., Hryniewicz, K., Sandy, M.R., Hurum, J.H., Druckenmiller, P., Knutsen, E.M. \& Høyberget, M. 2011: Hydrocarbon seeps from close to the Jurassic-Cretaceous boundary, Svalbard. Palaeogeography, Palaeoclimatology, Palaeoecology 306, 11-26. 
Hammer, Ø., Collignon, M. \& Nakrem, H.A. 2012: Organic carbon isotope chemostratigraphy and cyclostratigraphy in the Volgian of Svalbard. Norwegian Journal of Geology 92, 55-112.

Hansley, P.L. \& Spirakis, C.S. 1992: Organic matter diagenesis as the key to a unifying theory for the genesis of tabular uranium- vanadium deposits in the Morrison Formation, Colorado Plateau. Economic Geology, 87, 352-365.

Hjálmarsdóttir, H.R., Nakrem, H. \& Nagy, J. 2012: Foraminifera from Late Jurassic- Early Cretaceous hydrocarbon seep carbonates, central Spitsbergen, Svalbard - preliminary results. Norwegian Journal of Geology 92, 157-165.

Hryniewicz, K., Hammer, Ø., Nakrem, H.A. \& Little, C.T.S. 2012: Microfacies of the Volgian- Ryazanian (Jurassic- Cretaceous) hydrocarbon seep carbonates from Sassenfjorden, central Spitsbergen, Svalbard. Norwegian Journal of Geology 92, 113-131.

Hurum, J.H., Nakrem, H.A., Hammer, Ø., Knutsen, E.M., Druckenmiller, P.S., Hryniewicz K. \& Novis L.K. 2012: An Arctic Lagerstätte - the Slottsmøya Member of the Agardhfjellet Formation of Spitsbergen. Norwegian Journal of Geology 92, 55-64.

Kitamura, A. 1998: Glaucony and carbonate grains as indicators of the condensed section: Omma Formation, Japan. Sedimentary Geology 122, 151-163.

Mørk, A., Dallmann, W.K., Dypvik, H., Johannessen, E.P., Larssen, G.B., Nagy, J., Nøttvedt, A., Olaussen, S., Pcelina, T.M. \& Worsley, D. 1999: Mesozoic Lithostratigraphy. In Dallmann, W.K. (ed.): Lithostratigraphic Lexicon of Svalbard, Norsk Polarinstitutt, Tromsø, pp. 127-213.

Nagy, J. \& Basov, V.A. 1998: Revised foraminifera taxa and biostratigraphy of Bathonian to Ryazanian deposits in Spitsbergen. Micropaleontology 44, 217-255.

Nagy, J., Reolid, M. \& Rodriguez-Tovar, F.J. 2009: Foraminiferal morphogroups in dysoxic shelf deposits from the Jurassic of Spitsbergen. Polar Research 28, 214-221.

Ogg, J.G., and Hinnov, L.A., 2012. Jurassic. In Gradstein, F.M., Ogg, J.G., Schmitz, M.D., \& Ogg, G.M. (eds.): The Geologic Time Scale 2012, Elsevier Publ, 731-792.

Palliani, R.B. \& Riding, J.B. 2003: Biostratigraphy, Provincialism and Evolution of European Early Jurassic (Pliensbachian to Early Toarcian) Dinoflagellate Cysts. Palynology 27, 179-214.

Parker, J.R. 1967: The Jurassic and Cretaceous sequence in Spitsbergen. Geological Magazine 104, 487-505.

Pfiester, L.A. \& Anderson, D.M. 1987: Dinoflagellate life- cycle and their environmental control. In Taylor, F.J.R. (ed.): The biology of dinoflagellates, Botanical Monographs 21, Blackwell Scientific Publications, Oxford, pp. 611-648.

Prasad, V., Garg, R., Singh, V. \& Thakur, B. 2007: Organic matter distribution pattern in Arabian Sea: Palynofacies analysis from the surface sediments off Karwar coast (west coast of India). Indian Journal of Marine Sciences 36, 399-406.

Revill, A.T., Volkman, J.K., O'Leary, T., Summon, R.E., Boreham, C.J., Bank M.R. \& Denwer, K. 1994: Hydrocarbon biomarkers, thermal maturity, and depositional setting of tasmanite oil shales from Tasmania, Australia. Geochimica et Cosmochimica Acta 58, 38033822.

Riding, J.B., \& Sarjeant, W.A.S. 1985: The role of dinoflagellate cysts in the biostratigraphical subdivision of the Jurassic System. Newsletters on Stratigraphy 14, 96-109.

Riding, J.B., Fedorova, V.A. \& Ilyina, V.I. 1999: Jurassic and lowermost Cretaceous Dinoflagellate cyst Biostratigraphy of the Russian platform and Northern Siberia, Russia. The Palynological Society Contributions Series 36, $184 \mathrm{pp}$.

Rousseau, J. \& Nakrem, H. 2012: An Upper Jurassic Boreal Lagerstätte from Janusfellet, central Spitsbergen. Norwegian Journal of Geology 92, 133-161.

Smelror, M. \& Dypvik, H. 2005: Marine microplankton biostratigraphy of the Volgian- Ryazanian boundary strata, western Barents Shelf. Norges geologiske undersøkelse Bulletin 443, 61-69.
Smelror, M. \& Dypvik, H. 2006: The sweet aftermath: Environmental changes and biotic restoration following the marine Mjølnir impact (Volgian-Ryazanian boundary, Barents Shelf). In Cockell, C.S., Koeberl, C. \& Gilmour, I. (eds.): Biologial Processes Associated with Impact Events, Springer-Verlag, Berlin, pp. 143-178.

Smelror, M., Mørk, A., Monteil, E., Rutledge, D. \& Leereveld, H. 1998: The Klippfisk Formation - a lithostratigraphic unit of Lower Cretaceous platform carbonates on the Western Barents Shelf. Polar Research 17, 181-202.

Smelror, M. Dypvik, H. \& Mørk. A. 2002: Phytoplankton blooms in the Jurassic-Cretaceous boundary beds in the Barents Sea possibly induced by the Mjølnir impact. In Buffetaut, E. \& Koeberl, C. (eds.): Geological and Biological Effects of Impact Events, Springer-Verlag, Berlin, pp. 69-81

Smelror, M., Petrov, O.V., Larssen, G.B. \& Werner, S. (eds.) 2009: Atlas: Geological history of the Barents Sea. Geological Survey of Norway, Trondheim, $134 \mathrm{pp}$.

Tyson, R.V. 1993: Palynofacies analysis. In Jenkins, D.G. (ed.): Applied Micropaleontology, Kluwer Academic Publishers, Amsterdam, The Netherlands, pp. 153-191.

Tyson, R.V. 1995: Sedimentary Organic Matter. Organic facies and palynofacies. Chapman and Hall, London, 615 pp.

Van der Zwan, C.J. 1990: Palynostratigraphy and Palynofacies Reconstruction of the Upper Jurassic to Lowermost Cretaceous of the Draugen Field, Offshore Mid Norway. Review of Palaeobotany and Palynology 62, 157-186.

Van Wagoner, J.C., Posamentier, H.W., Michum, R.M., Vail, P.R., Sarg, J.F., Loutit, T.S. \& Hardenbol, J. 1988: An overview of the fundamentals of sequence stratigraphy and key definitions. In Wilgus, C.K. (ed.): Sea-level changes: An Intergrated Approach, Society of Economic Paleontologists and Mineralogists Special Publication 42, Tulsa, pp. 39-45.

Wierzbowski, A., Hryniewitcz., K., Hammer, Ø., Nakrem, H.A. \& Little, C.T.S. 2011: Ammonites from hydrocarbon seep carbonate bodies from the uppermost Jurassic- lowermost Cretaceous of Spitsbergen and their biostratigraphical importance. Neues Jahrbuch für Geologie und Paläontologie - Abhandlungen 262, 267-288.

Århus, N. 1988: Palynostratigraphy of some Bathonian- Hauterivian sections in the Arctic, with emphasis on the Janusfjellet Formation type section, Spitsbergen. Institutt for Kontinentalsokkelundersøkelser (IKU) Report 23.1252.11/01/88, 139 pp. 